$\overline{\text { Original }}$

\title{
Desmutagenic Effect of Pheophytin from Japanese Eggplant against Several Mutagens
}

\author{
(Received May 13, 1996)
}

\author{
Kentaro Yoshikawa*1, Katsuhiro Inagaki*1, Takao Terashita*1, \\ Jiko Shishiy ama*1 and Delbert M. Shankel ${ }^{* 2}$ \\ ${ }^{* 1}$ Department of Food and Nutrition, Kinki University: 3327-204, Nakamachi, \\ Nara 631, Japan; *2Department of Microbiology, The University \\ of Kansas: Lawrence, KS 66049, U.S.A.)
}

\begin{abstract}
Using Salmonella typhimurium TA98 in the Ames test, we have identified desmutagens in Japanese eggplant juice. Most of the desmutagenic activity in the eggplant fruit is due to pheophytin, a Mg-free derivative of chlorophyll. Pheophytin inhibits mutagenesis to about $40 \%$ with or without metabolic activation of mutagens by S9 mix preparations. The mutagens employed were 2-aminoanthracene (2-AA), 2-aminofluorene (2-AF), 2-amino-3-methyl-9Hpyrido[2,3-b]indole $(\mathrm{MeA} \alpha \mathrm{C}), 3$-amino-1-methyl-5H-pyrido[4,3-b]indole (Trp-P-2) and 2-nitrofluorene (2-NF). Pheophytin did not influence enzymes involved in metabolic activation or interfere with the activation process when S9 was added. Therefore pheophytin appears to be a desmutagen acting directly on the mutagens. Trp-P-2-pheophytin reaction products could not be isolated by HPLC or determined by ${ }^{1} \mathrm{H}$-NMR under various conditions owing to their instability. The desmutagenicity of pheophorbide, the phorbin skeleton of pheophytin, against Trp-P-2 was approximately $40 \%$, but phytol, the carbon chain of pheophorbide, showed no desmutagenicity. This suggests that the desmutagenicity of pheophytin is derived from the pyrole rings.
\end{abstract}

Key words: desmutagenicity; pheophytin; chlorophyll; Salmonella typhimurium TA98

\section{Introduction}

There are many reports about the desmutagenicity of eggplant ${ }^{1-4)}$. It has been reported that the Japanese eggplant fruit shows a carcinostatic effect ${ }^{5}$. Also, in a previous report, we have isolated several desmutagens from Japanese eggplant juice ${ }^{6}$. They were pheophytin, (the $\mathrm{Mg}$-free derivative of chlorophyll), lutein, pheophorbide or chlorophyllide, and tannin-containing sugars. Among these agents, the relative content of pheophytin in the eggplant fruit was the highest, so it was regarded as the principal desmutagen in the eggplant fruit. It remains to be seen whether this compound may be useful for the practical chemo-prevention of mutations and cancer. It is important to study its desmutagenic (and potential anticarcinogenic) effects and to clarify its properties and mecha- nism of action. It has already been reported that chlorophyll and chlorophyllin are desmutagenic against heterocyclic amines ${ }^{7)}$ and $\mathrm{B}(\mathrm{a}) \mathrm{P}^{8)}$. The activities of pheophytin $a$ and $b$ from vegetables, however, have not been clarified. Thus, using Salmonella typhimurium TA98 as a test organism, we have investigated the mechanism of the desmutagenic effect of pheophytin.

\section{Materials and Methods}

\section{Chemicals}

Chemicals used were of the purest grade commercially available.

2-Aminoanthracene (2-AA), 2-amino-3-methyl$9 H$-pyrido[2,3-b]indole $(\mathrm{MeA} \alpha \mathrm{C})$ and 3 -amino-1methyl-5H-pyrido[4,3-b]indole (Trp-P-2) were obtained from Wako Pure Chemical Ind., Ltd. (Tokyo), and 2-aminofluorene (2-AF) and 2nitrofluorene (2-NF) from Tokyo Kasei Co., Inc. 
(Tokyo).

\section{Extraction}

Fresh eggplant fruits (Solanum melongena L.) were purchased from a supermarket in Nara city, Japan. Pheophytin $a$ and $b$ were isolated from the petroleum ether layer of a supernatant obtained from homogenized eggplant juice ${ }^{6)}$.

\section{Desmutagenicity assay}

The desmutagenic effects of pheophytin, chlorophyll, pheophorbide and phytol were assayed using the Ames methods ${ }^{9}$ after the addition of a test compound to the system. To the mixture of mutagen and desmutagen, phosphate buffer $(\mathrm{pH}$ 7.0) was added, and the mixture was shaken for $30 \mathrm{~min}$ at $37^{\circ} \mathrm{C}$, then heated at $100^{\circ} \mathrm{C}$ for $3 \mathrm{~min}$. The mixture was filtered using a membrane filter $(0.45 \mu \mathrm{m})$ and the filtrate was assayed. The procedure was as described by Mitscher et $a l . .^{10)}$, Shankel and Clarke ${ }^{11)}$ and Yoshikawa et $a l .{ }^{12)}$. The mutagens used required $\mathrm{S} 9 \mathrm{mix}$ for metabolic activation, except for 2-NF. Each set of experiments was run in triplicate and repeated at least 3 times.

\section{Preparation of activated Trp-P-2 ${ }^{13)}$}

A mixture of $1.0 \mathrm{ml}$ of $50 \mu M$ Trp-P-2 (in DMSO) and $3.0 \mathrm{ml}$ of S9 mix was shaken for 30 $\min$ at $37^{\circ} \mathrm{C}$ and then $4.0 \mathrm{ml}$ of acetone was added and the mixture was allowed to settle for $20 \mathrm{~min}$ in an ice bath after having been well shaken. The solution was centrifuged $(7,000 \times g$, $4^{\circ} \mathrm{C}, 15 \mathrm{~min}$ ), and the supernatant was evaporated at $50^{\circ} \mathrm{C}$ under reduced pressure. The activated Trp-P-2 in the dry residue was dissolved in $1.0 \mathrm{ml}$ of distilled water and the solution was filtered through a membrane filter $(0.45 \mu \mathrm{m})$.

\section{Changes of Trp-P-2 absorbance profile resulting from addition of pheophytin $a$ and $b$}

Pheophytin $a$ or $b(0-7.5 \mu M)$ in acetonitrile was mixed with Trp-P-2 $(25 \mu M)$ in $1 / 15 M$ phosphate buffer ( $\mathrm{pH} 7.0)$ and absorbance was measured at 200-400 $\mathrm{nm}$ with a Shimadzu UVvisible recording spectrophotometer UV-160.

\section{Changes of absorbance profile of pheophytin on addition of Trp-P-2}

Trp-P-2 (0-100 $\mu M)$ was mixed with pheophy- tin a $(20 \mu M)$ in $1 / 15 M$ phosphate buffer $(\mathrm{pH}$ 7.0 ) and the absorbance profile of pheophytin $a$ was measured as described above.

\section{HPLC analysis}

To a mixture of $0.5 \mathrm{ml}$ of $50 \mathrm{n} M$ Trp-P-2 (in DMSO) and $0.1 \mathrm{ml}$ of $10 \mathrm{n} M$ pheophytin $a$ in acetonitrile, $0.4 \mathrm{ml}$ of $1 / 15 \mathrm{M}$ phosphate buffer was added, and the whole was shaken for $30 \mathrm{~min}$ at $37^{\circ} \mathrm{C}$, then heated at $100^{\circ} \mathrm{C}$ for $3 \mathrm{~min}$. The reaction mixture $(10 \mu 1)$ was filtered using a membrane filter $(0.45 \mu \mathrm{m})$ and the filtrate was analyzed using a Shimadzu Liquid Chromatograph LC-3A with a Wakosil $5 \mathrm{C} 18(4.6 \phi \times 200$ $\mathrm{mm})$ column. The mobile phase was $30 \%$ acetonitrile/20 mM KH $\mathrm{KHO}_{2}$ (pH 4.5). The flow rate was $0.7 \mathrm{ml} / \mathrm{min}$, and peaks were detected by measuring the absorbance at $265 \mathrm{~nm}$.

\section{8. ${ }^{1} \mathrm{H}-\mathrm{NMR}$ analysis}

A mixture of $0.1 \mathrm{ml}$ of $16 \mu M$ Trp-P-2 in distilled water and $0.5 \mathrm{ml}$ of $4 \mu \mathrm{M}$ pheophytin a in acetonitrile was shaken for $30 \mathrm{~min}$ at $37^{\circ} \mathrm{C}$. The solution was heated at $100^{\circ} \mathrm{C}$ for $5 \mathrm{~min}$, then filtered through a membrane filter $(0.45 \mu \mathrm{m})$. The solution was evaporated at $50^{\circ} \mathrm{C}$ under reduced pressure, and the dry residue was dissolved in dimethylsulfoxide- $d_{6}$. As a control, the ${ }^{1} \mathrm{H}-\mathrm{NMR}$ spectra of this solution without pheophytin was measured using a JNM GX-270 Spectrometer (Nippon Denshi Co., Inc.).

\section{Results}

\section{Desmutagenicity assay}

Using Salmonella typhimurium strain TA98 in the Ames test we have previously shown that several desmutagens exist in Japanese eggplant juice. The desmutagenicity of pheophytin $a$ and $b$ in eggplant juice against mutagenesis by several promutagens (2-AA, 2-AF, MeA $\alpha \mathrm{C}$, Trp-P-2) with S9 mix, and by a direct mutagen $(2-\mathrm{NF})$ without S9 mix was examined. The results are shown in Table 1. Pheophytin $a$ and $b$ inhibited mutagenicity by $31-47 \%$ at the highest concentrations used. This effect was independent of the presence of S9 mix. After the incubation of Trp-P-2 with the pheophytin $a$ or $b$, the pheophytin was separated from the reaction mixture, and the mutagenicity of Trp-P-2 was assayed. The mutagenicity of Trp-P-2 without S9 mix 
Table 1. Desmutagenicity of Pheophytin from Eggplant against Several Mutagens in a Salmonella typhimurium TA98 Test System

\begin{tabular}{|c|c|c|c|c|c|c|c|}
\hline & \multicolumn{3}{|c|}{$\begin{array}{c}2-\mathrm{AA} \\
(10 \mathrm{nmol} / \text { plate })\end{array}$} & \multicolumn{2}{|c|}{$\begin{array}{c}2-\mathrm{AF} \\
(10 \mathrm{nmol} / \text { plate })\end{array}$} & \multicolumn{2}{|c|}{$\begin{array}{c}\text { Trp-P-2 } \\
(10 \mathrm{nmol} / \text { plate })\end{array}$} \\
\hline & $\begin{array}{l}\text { Average } \\
\text { number of } \\
\text { revertants }\end{array}$ & \multicolumn{2}{|c|}{$\begin{array}{c}\text { Percent } \\
\text { reduction of } \\
\text { revertants }(\%)\end{array}$} & $\begin{array}{l}\text { Average } \\
\text { number of } \\
\text { revertants }\end{array}$ & $\begin{array}{c}\text { Percent } \\
\text { reduction of } \\
\text { revertants (\%) }\end{array}$ & $\begin{array}{l}\text { Average } \\
\text { number of } \\
\text { revertants }\end{array}$ & $\begin{array}{c}\text { Percent } \\
\text { reduction of } \\
\text { revertants }(\%)\end{array}$ \\
\hline \multicolumn{8}{|c|}{ Pheophytin $a$ (nmol/plate) } \\
\hline 0 & \multicolumn{2}{|l|}{862} & 0 & 784 & 0 & 1462 & 0 \\
\hline 1.0 & 686 & \multicolumn{2}{|c|}{21} & 655 & 17 & 1232 & 16 \\
\hline 2.0 & 661 & \multicolumn{2}{|c|}{24} & 617 & 22 & 1046 & 29 \\
\hline 4.0 & 586 & \multicolumn{2}{|c|}{33} & 549 & 31 & 873 & 41 \\
\hline 8.0 & 586 & \multicolumn{2}{|c|}{33} & 469 & 42 & 873 & 41 \\
\hline Pheophytin & (nmol/plate) & & & & & & \\
\hline 0 & 862 & & 0 & 784 & 0 & 1462 & 0 \\
\hline 1.0 & 720 & & 17 & 610 & 23 & 1304 & 11 \\
\hline 2.0 & 661 & & 24 & 617 & 22 & 1074 & 27 \\
\hline 4.0 & 493 & & 14 & 496 & 38 & 902 & 39 \\
\hline 8.0 & 494 & & 14 & 480 & 40 & 887 & 40 \\
\hline & & $(10 \mathrm{nr}$ & $\begin{array}{l}\mathrm{NF} \\
\mathrm{ol} / \text { plate })\end{array}$ & & & $\begin{array}{r}\mathrm{M} \\
(25 \mathrm{nn}\end{array}$ & $\begin{array}{l}\mathrm{A} \alpha \mathrm{C} \\
\mathrm{ol} / \text { plate })\end{array}$ \\
\hline & $\begin{array}{l}\text { Av } \\
\text { nun } \\
\text { rev }\end{array}$ & $\begin{array}{l}\text { erage } \\
\text { iber of } \\
\text { ertants }\end{array}$ & $\begin{array}{r}\text { Perc } \\
\text { reduct } \\
\text { revertar }\end{array}$ & $\begin{array}{l}\text { ent } \\
\text { ion of } \\
\text { ats }(\%)\end{array}$ & & $\begin{array}{l}\text { Average } \\
\text { number of } \\
\text { revertants }\end{array}$ & $\begin{array}{c}\text { Percent } \\
\text { reduction of } \\
\text { revertants }(\%)\end{array}$ \\
\hline Pheophyti & (nmol/plate & & & & eophytin $a$ (nmol & Plate) & \\
\hline 0 & & 674 & ( & & 0 & 880 & 0 \\
\hline 1.0 & & 577 & 15 & & 1.5 & 735 & 17 \\
\hline 2.0 & & 447 & 3 & & 3.0 & 658 & 26 \\
\hline 4.0 & & 382 & 4 & & 6.0 & 538 & 40 \\
\hline 8.0 & & 369 & 4 & & 9.0 & 495 & 45 \\
\hline Pleophytir & (nmol/plate) & & & & ophytin $b$ (nmol & (plate) & \\
\hline 0 & & 674 & ( & ) & 0 & 880 & 0 \\
\hline 1.0 & & 590 & 1 & & 1.5 & 795 & 10 \\
\hline 2.0 & & 460 & 3 & & 3.0 & 718 & 19 \\
\hline 4.0 & & 401 & 4 & & 6.0 & 598 & 33 \\
\hline 8.0 & & 388 & 4 & & 9.0 & 615 & 31 \\
\hline
\end{tabular}

The average number of spontaneous revertants/plate in these experiments was 25 .

was directly inhibited by pheophytin $a$ and $b$, but pheophytin $a$ and $b$ showed no desmutagenicity at all against activated Trp-P-2 (Table 2), obtained by extraction with acetone after incubation of the Trp-P-2 alone with S9 mix.

2. Change of Trp-P-2 absorbance resulting from addition of pheophytin and change of absorbance of pheophytin on addition of Trp-P-2

$\mathrm{UV}$ and visible absorption spectra were followed during mutual addition of Trp-P-2 and pheophytin to study the mechanism of the in- hibitory action. Decreases in absorbance occurred over the range from $205-240 \mathrm{~nm}$ and the absorbance of $25 \mu M$ Trp-P-2 at $210 \mathrm{~nm}$ was decreased by about $50 \%$ when $6.0 \mu M$ pheophytin $a$ was mixed with it. Addition of pheophytin $b$ also caused a decrease of about 20\% (Fig. 1). The absorbance of $20 \mu M$ pheophytin $a$ when mixed with 0-100 $\mu M$ Trp-P-2 decreased over the range from $200-280 \mathrm{~nm}$. The absorbance of $20 \mu M$ pheophytin $a$ decreased by about $50 \%$ at $210 \mathrm{~nm}$, and decreased $100 \%$ at $265 \mathrm{~nm}$ upon addition of $80 \mu M$ Trp-P-2 (Fig. 2). 
Table 2. Desmutagenicity of the Pheophytin from Eggplant against Mutagenicity of Trp-P-2 and Activated Trp-P-2 in Salmonella typhimurium TA98

\begin{tabular}{lcc}
\hline \hline \multirow{2}{*}{ Mutagen } & \multicolumn{2}{c}{ Desmutagenicity $(\%)^{\mathrm{a}}$} \\
\cline { 2 - 3 } & Pheophytin & Pheophytin \\
& $a$ & $b$ \\
\hline Trp-P-2 & 38.7 & 38.8 \\
Activated Trp-P-2 & 0.0 & 4.3 \\
\hline
\end{tabular}

a The percent reduction in frequency of his ${ }^{-}$to his $^{+}$revertants.

Trp-P-2 or activated Trp-P-2 $(5 \mathrm{nmol})$ was incubated at $37^{\circ} \mathrm{C}$ for $30 \mathrm{~min}$ with pheophytin $a$ or $b(1.8 \mathrm{nmoi})$ from eggplant, then the mixture was heated at $100^{\circ} \mathrm{C}$ for $3 \mathrm{~min}$ and filtered $(0.45$ $\mu \mathrm{m})$. The desmutagenicity of pheophytin $a$ or $b$ against the mutagenicity of Trp-P-2 with S9 mix or activated Trp-P-2 without S9 mix was assayed.

b For details of the preparation of activated Trp$\mathrm{P}-2$, see the text.

\section{HPLC analysis and ${ }^{1} H-N M R$ analysis}

We tried to isolate a possible reaction product by means of HPLC using a Wakosil 5C18 column. The chromatograms of Trp-P-2 both with and without pheophytin $a$ showed a peak at a retention time of $11.7 \mathrm{~min}$. In addition, the ${ }^{1} \mathrm{H}-\mathrm{NMR}$ spectra were exactly the same. Further study is required.

\section{Desmutagenicity of chlorophyll, pheophorbide and phytol}

Chlorophyll $a$ and $b$, the Mg salt of pheophytin, inhibited the mutagenicity of Trp-P-2 (Table $3)$. Pheophorbide, the phorbin skeleton of pheophytin, at a concentration of $5 \mathrm{n} M$, inhibited by $40 \%$ the mutagenicity of $1.2 \mathrm{n} M$ Trp-P-2. Phytol did not show any desmutagenic activity (Table 4).

\section{Discussion}

From the cancer-prevention point of view, it is important to determine the stability of desmutagens and potential anticarcinogens in vivo, the specificity of a desmutagen to mutagens and the mechanisms of action of desmutagens in foods. There are many reports on the desmutagenicity of chlorophyll and chlorophyllin from vegetables, but details of the activity of pheophytin

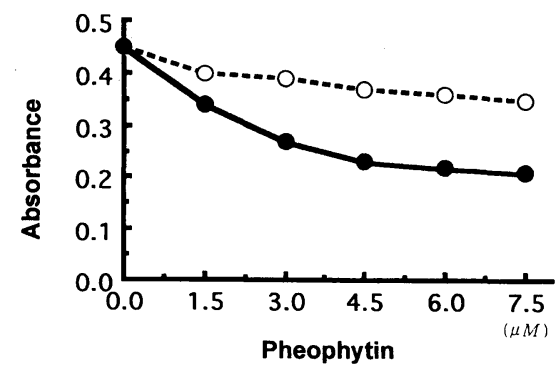

Fig. 1. Changes of absorbance of Trp-P-2 by pheophytin

0-7.5 $\mu M$ pheophytin $a(\bullet)$ or $b(\bigcirc)$ from eggplant was mixed with Trp-P-2 $(25 \mu M)$. The absorbance of Trp-P-2 at $210 \mathrm{~nm}$ was measured with a spectrophotometer.

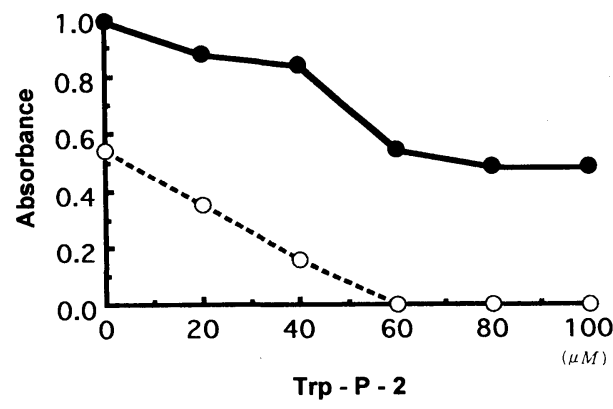

Fig. 2. Changes of absorbance of pheophytin $a$ by Trp-P-2

0-100 $\mu M$ Trp-P-2 was mixed with pheophytin $a(20 \mu M)$. The absorbance of pheophytin $a$ at $210 \mathrm{~nm} \mathrm{(O)}$ and $265 \mathrm{~nm}$ (○) was measured with a spectrophotometer.

from vegetables have not yet been clarified. Thus, in this study, some of the properties and desmutagenic mechanisms of pheophytin from Japanese eggplant were examined.

The desmutagenic properties of pheophytin isolated from eggplant were stable at $100^{\circ} \mathrm{C}$ for $10 \mathrm{~min}$, which is consistent with the fact that cooked green vegetables maintain this effect even after cooking ${ }^{6}$.

When tested using S. typhimurium TA98, pheophytins inhibited mutagenesis by 2-AA, 2-AF, $\mathrm{MeA} \alpha \mathrm{C}$, Trp-P- 2 or $2-\mathrm{NF}$ by about $40 \%$ with or without metabolic activation of the mutagens with S9 preparations. These results indicated that pheophytin is active against these mutagens, but did not enhance metabolic activation enzymes or interfere with the course of the ac- 
Table 3. Desmutagenicity of Chlorophyll against the Mutagenicity of Trp-P-2 to Salmonella typhimurium TA98

\begin{tabular}{ccc}
\hline \hline & \multicolumn{2}{c}{$\begin{array}{c}\text { Trp-P-2 } \\
\text { (5mol/plate) }\end{array}$} \\
\cline { 2 - 2 } & $\begin{array}{c}\text { Average } \\
\text { number of } \\
\text { revertants }\end{array}$ & $\begin{array}{c}\text { Percent } \\
\text { reduction of } \\
\text { revertants (\%) }\end{array}$ \\
\hline Chlorophyll $a$ (nmol/plate) & \\
0 & 902 & 0 \\
0.6 & 816 & 10 \\
1.2 & 584 & 37 \\
1.8 & 619 & 33 \\
2.4 & 558 & 40 \\
Chlorophyll $b$ (nmol/plate) & 0 \\
0 & 902 & 22 \\
0.6 & 709 & 33 \\
1.2 & 619 & 40 \\
1.8 & 558 & 40 \\
\hline .4 & 560 & \\
\hline
\end{tabular}

The average number of spontaneous revertants/plate in these experiments was 43 .

tivation process. Further, pheophytin did not show any desmutagenicity against activated Trp-P-2, obtained by extraction with acetone after incubating Trp-P-2 alone with S9 mix, though Trp-P-2 with S9 mix was directly inhibited. When Trp-P-2 was recovered from the mixture of Trp-P-2 and pheophytin by heating at $100^{\circ} \mathrm{C}$ for $3 \mathrm{~min}$ followed by filtration $(0.45$ $\mu \mathrm{m})$, the mutagenicity was reduced; when the mixed Trp-P-2 was separated from the pheophytin, the mutagenicity was still reduced. From these results, we believe that pheophytin is a desmutagen acting directly on mutagens to inhibit their mutagenicity.

With regard to its mechanism of action, changes were noted in the UV and visible absorption spectra of Trp-P-2 and pheophytins upon mixing them (Fig. 2). This seems to indicate that a reaction had occurred due to the conversion of Trp-P-2 to Trp-P-2-pheophytin complex, resulting in inhibition of mutagenesis even after removal of pheophytin. Arimoto et $a l .{ }^{14)}$, Dashwood et al. ${ }^{15)}$, Negishi et al. ${ }^{16)}$ and Guo et al. ${ }^{17)}$ have shown that hemin and chlorophyll inactivated Trp-P-2 and some other heterocyclic amines by complex formation. However, Romert et al. ${ }^{18)}$ suggested that low doses of chlo-
Table 4. Desmutagenicity of Pheophorbide a and Phytol against the Mutagenicity of Trp-P-2 to Salmonella typhimurium TA98

\begin{tabular}{ccc}
\hline & \multicolumn{2}{c}{ Trp-P-2 } \\
& \multicolumn{2}{c}{$(5 \mathrm{nmol} /$ plate $)$} \\
\cline { 2 - 3 } & $\begin{array}{c}\text { Average } \\
\text { number of } \\
\text { revertants }\end{array}$ & $\begin{array}{c}\text { Percent } \\
\text { reduction of } \\
\text { revertants (\%) }\end{array}$ \\
\hline Pheophorbide $a$ (nmol/plate) & \\
0 & 844 & 0 \\
0.6 & 649 & 24 \\
1.2 & 511 & 41 \\
1.8 & 503 & 42 \\
2.4 & 511 & 41 \\
Phytol (nmol/plate) & & 0 \\
0 & 844 & -3 \\
0.6 & 868 & 4 \\
1.2 & 812 & -4 \\
1.8 & 876 & -1 \\
2.4 & 852 & \\
\hline
\end{tabular}

The average number of spontaneous revertants/plate in these experiments was 32 .

rophyllin may interact with the electron transport system involved in activation, due to its redox cycling capacity.

To study the putative Trp-P-2-pheophytin complex further, we attempted to isolate the complex by means of HPLC, but were not succecessful. In addition, no change of the ${ }^{1} \mathrm{H}-\mathrm{NMR}$ spectrum was apparent. Thus, the complex of Trp-P-2 with pheophytins may be unstable, reverting to the initial state under various conditions.

Pheophytin has a phorbin skeleton, and its metallic salts (chlorophyll, chlorophyllin) have desmutagenicity. Therefore, several related compounds were examined for desmutagenicity in the Ames test. Romert et al. ${ }^{19)}$ reported that biliverdin, which has a porphyrin structure (but without the central metal ion) had no effect on the mutagenicity of nitrosamine in the Ames test. These results, indicated that the chelated metal ion is essential for the effect. The desmutagenicity of chlorophyllin was greater than that of chlorophyll because of the presence of $\mathrm{Cu}$ in chlorophyllin ${ }^{16), 19)}$. Since the desmutagenicity of pheophytin against Trp-P-2 is roughly similar to that of chlorophyll in terms of the doseresponse relation (Table 3 ), we postulate that the 
<smiles>[Y]=CCCC(=O)O</smiles>

Fig. 3. Structure of pheophorbide<smiles>CC(=CCO)CCC[C@@H](C)CCC[C@@H](C)CCCC(C)C</smiles>

Fig. 4. Structure of phytol

presence of $\mathrm{Mg}$ in the phorbin skeleton does not influence the desmutagenicity of pheophytin. Pheophorbide (Fig. 3), the phorbin skeleton of pheophytin, against Trp-P-2 was desmutagenic, but phytol (Fig. 4), the carbon chain of pheophytin ${ }^{20)}$, was not. Since the desmutagenicity of pheophytin seems to be manifested mainly by the phorbin skeleton, the pyrole rings may be important. This is supported by the fact that the desmutagenicity of heme and hemin results from bilirubin and biliverdin ${ }^{13)}$.

Using S. typhimurium TA98 in Ames tests, we have shown that pheophytin from Japanese eggplant fruit is a desmutagen. However, the precise interaction between pheophytin and mutagens leading to this effect was not elucidated. Further studies are in progress.

\section{Acknowledgments}

We are grateful to the Environmental Science Institute of Kinki University for financial support. This study was also supported by a Grantin-Aid for Scientific: Research from the Japan Private School Promotion Foundation.

\section{References}

1) Morita, H., Hara, M., Kada, T.: Agric. Biol. Chem. 42, 1,235-1,238 (1978).

2) Kada, T.: Toxicology Forum 6, 580-589 (1983).

3) Shinohara, K., Kuroki, S., Miwa, M., Kong, Z., Hosoda, H.: Agric. Biol. Chem. 52, 1,369-1,375 (1988).

4) Yoshikawa, K., Mui, K., Ishii, R., Terashita, T., Shishiyama, J., Kono, M.: Mem. Fac. Agr. Kinki Univ. 23, 55-61 (1990).

5) Samaru, Y.: Japan Food Science 3, 76-81 (1989).

6) Yoshikawa, K., Inagaki, K., Terashita, T., Shishiyama, J., Kuo, S., Shankel, D. M.: Mutation Res. submitted (1996).

7) Arimoto, S., Negishi, T., Hayatsu, H.: Cancer Lett. 11, 28-33 (1980).

8) Terwel, L., Hoeven, J. C. M.: Mutation Res., 152, 1-4 (1985).

9) Ames, B. N., McCann, J., Yamasaki, E.: ibid. 31, 347-364 (1975).

10) Mitscher, L. A., Drake, S., Gollapudi, S. R., Harris, J. A., Shankel, D. M., in: Shankel, D. M., Hartman, P. E., Kada, T., Hollaender, A. ed.: "Antimutagenesis and Anticarcinogenesis Mechanisms" p. 153-165 (1986), Basic Life Sciences 39, Plenum Press, New York.

11) Shankel, D. M., Clarke, C. H., in: Kuroda, Y., Shankel, D. M., Waters, M. D. ed.: “Antimutagenesis and Anticarcinogenesis Mechanisms II" p. 457460 (1990), Basic Life Sciences 52, Plenum Press, New York.

12) Yoshikawa, K., Inagaki, K., Murao, R., Terashita, T., Shishiyama, J.: Annals of the Environmental Science Research Institute, Kinki Univ. 19, 1-5 (1991).

13) Arimoto, S., Hayatsu, H.: Mutation Res. 213, 217-226 (1989).

14) Arimoto, S., Ohara, Y., Namba, T., Negishi, T., Hayatsu, H.: Biochem. Biophys. Res. Commun. 92, 662-668 (1980).

15) Dashwood, R. H., Breinholt, V., Bailey, G. S.: Carcinogenesis 12, 939-942 (1991).

16) Negishi, T., Arimoto, S., Nishizaki, C., Hayatsu, H.: ibid. 10, 145-149 (1989).

17) Guo, D., Horio, D., Grove, J., Dashwood, R.: Cancer Lett. 95, 161-165 (1995).

18) Romert, L., Curvall, M., Jenssen, D.: Mutagenesis 7, 349-355 (1992).

19) Sato, T., Ose, Y., Nagase, H., Kito, H.: Mutation Res. 241, 283-290 (1990).

20) Iriyama, K.: Protein, Nucleic Acid and Enzyme 18, 69-75 (1973). 